\title{
Mesleki ve Teknik Liselerde İnformal İletişim ${ }^{1}$
}

\author{
Ali CÜLHA \\ Dr., MEB \\ ali.63.44@hotmail.com
}

Orcid ID: https://orcid.org/0000-0002-5215-0823

\author{
Ahmet KAYA \\ Doç. Dr., Kahramanmaraş Sütçü İmam Üniversitesi \\ Eğitim Fakültesi, Eğitim Yönetimi Ana Bilim Dalı \\ akaya574@hotmail.com \\ Orcid ID: https://orcid.org/0000-0001-8899-9178 \\ Betül DELİBALTA \\ Öğretmen, MEB \\ betuldelibalta4@gmail.com \\ Orcid ID: https://orcid.org/0000-0002-7947-1782
}

\begin{abstract}
Öz
$\mathrm{Bu}$ araştırmanın amacı mesleki ve teknik liselerde görev yapmakta olan yönetici ve öğretmenlerin informal iletişimi kullanma düzeylerini ortaya koyarak, informal iletişimin çeşitli değişkenlere göre farklılaşıp farklılaşmadığını tespit etmektir. Araştırmada nicel araştırma yöntemlerinden olan betimsel tarama modeli kullanılmıştır. Araştırmanın evrenini mesleki ve teknik liselerde görev yapan öğretmen ve yöneticiler oluşturmaktadır. Araştırmada, Toytok ve Doğan (2019) tarafindan geliştirilen, 5 boyut ve 23 maddeden oluşan okullarda informel iletişim ölçeği kullanılmıştır. Araştırmada ölçeğin Cronbach's Alpha iç tutarlılık katsayıs1 .84 olarak tespit edilmiştir. Verilerin analizinde aritmetik ortalama, tTesti ve tek yönlü varyans analizi testi kullanılmıştır. Araştırmada mesleki ve teknik liselerde görev yapmakta olan okul yöneticileri ve öğretmenlerin informal iletişim alg1 düzeylerinin ara sıra (orta) düzeyinde olduğu tespit edilmiştir. Mesleki k1demi 11-15 y1l arasında olanların mesleki kıdemi 0-5 yıl arasında olanlara göre, okulda çalışma süresi 6-10 yıl arasında olanların çalışma süresi 05 yıl olanlara göre, Eğitim Fakültesi mezunlarının Fen Edebiyat Fakültesi mezunlarına göre informal iletişim düzeylerinin daha yüksek olduğu ortaya çıkmıştır. Araştırma bulgularından hareketle informal iletişimle ilgili olarak
\end{abstract}

${ }^{1}$ Makale Geliș/Kabul Tarihi: 17.05.2021 / 13.07.2021

Künye Bilgisi: Cülha, A. Kaya, A. ve Delibalta, B. (2021). Mesleki ve teknik liselerde informal iletişim. Kahramanmaraş Sütçü Imam Üniversitesi Sosyal Bilimler Dergisi, 18 (3), 1527-1544. DOI: 10.33437/ksusbd.938343 
mesleki ve teknik liselerde görev yapmakta olan yönetici ve öğretmenlere bazı eğitimler, atölye çalışmaları düzenlenebilir. Aynı bölümler içerisinde ve farklı bölümler arasında iletişimi arttırabilecek sosyal ve kültürel organizasyonlar yapilabilir.

Anahtar Kelimeler: İletişim, İnformal İletişim, Mesleki ve Teknik Lise.

\title{
Informal Communication in Vocational and Technical High Schools
}

\begin{abstract}
The aim of this study is to determine whether informal communication differs according to various variables by revealing the level of informal communication use of administrators and teachers working in vocational and technical high schools. The descriptive survey model, which is one of the quantitative research methods, was used in the study. The population of the research consists of teachers and administrators working in vocational and technical high schools. In the study, the informal communication scale was used in schools, which was developed by Toytok and Doğan (2019) and consisted of 5 dimensions and 23 items. In the study, Cronbach's Alpha internal consistency coefficient of the scale was determined as .84 . Arithmetic mean, t-Test and one-way analysis of variance test were used to analyze the data. Those with a professional seniority of 11-15 years had a higher level of informal communication compared to those with a professional seniority of 0-5 years, those with a working period of 6-10 years at school compared to those with a working period of $0-5$ years, and that graduates of Faculty of Education had higher levels of informal communication than those with graduates of Faculty of Science and Literature. Based on the findings of the research, some trainings and workshops can be organized for administrators and teachers working in vocational and technical high schools regarding informal communication. Social and cultural organizations can be organized to increase communication within the same departments and between different departments.
\end{abstract}

Keywords: Communication, Informal Communication, Vocational and Technical High School.

\section{GİRIŞ}

Personel yönetimi bakımından dönüm noktası olarak görülebilecek Hawthorne araştırmaları ile birlikte, işgörenlere yönelik tutum ve davranışların önemli olduğu keşfedilmiş, insan ilişkileri akımı başlatmıştır. Bu akımla birlikte, yönetim faaliyetlerinin amacına ulaşmasında informal yapıların önemli katkılarının olduğu fark edilmiştir (Bursalığlu, 1971; Himmetoğlu, Ayduğ, ve Bayrak, 2020). Örgütlerde insan ilişkilerinin öneminin keşfedilmesiyle, informal iletişim kanallarıyla gelişen güçlü ilişkiler, bağllık, motivasyon, birlik ve 
beraberlik gibi unsurların değeri anlaşılmıştır. Bu nedenle, maksimum verimi hedefleyen örgütler daha etkili iletişim için çaba göstermekte, informal iletişimi formal iletişimin yanında ve onun tamamlayıcısı olarak, örgütsel etkililiğe katkıda bulunması için yaygın biçimde kullanılmaktadırlar (Himmetoğlu, Ayduğ, ve Bayrak, 2020; Riggio, 2016). Başka bir deyişle informal iletişim kanalları, örgütün bir gerçeği haline geldiğinden, bu kanalları tıkamak, akışı durdurmak ya da ortadan kaldırmak yerine, onun varlığını kabul ederek örgüt yararına kullanılmaktadır (Bektaş ve Erdem, 2015). İnformal iletişim, örgüt içinde mevcut olan formal ağların ötesine geçerek, bilginin yayılmasına yardımcı olur. Yayılan bilgi her zaman hoşa giden, istenilen bilgi olmayabilir. Bu olasılığa rağmen, informal iletişim sürecinin engellenmesi yerine yönetilmesi ve ondan yararlanılması daha değerlidir (Uğurlu, 2014). Örgütlerin yapısı da örgüt içindeki iletişim şekillerini etkilediğinden (Lunenburg, 2010) kendi doğasıyla pek de uyuşmayan bilimsel işletmenin ağırlığından sıkılan eğitim örgütlerinde de insan ilişkileri akımı yayılmış, informal örgüt yöneticiler tarafından kabul edilmiş ve yöneticilerin davranışlarını etkilemiştir. İnformal örgüt, çok gruplu olan eğitim örgütlerinde önemli etkileşim yapıları meydana getirme, işbirliğini arttırma, örgütün amaçlarının gerçekleştirilmesine katkıda bulunma noktasında rol oynamaktadır (Bursalığlu, 2012). Eğitim örgütlerinde iletişim ve informal iletişim ile ilgili birtakım çalışmalar mevcuttur (Afat ve Arslan, 2019; Ay ve Uğurlu, 2016; Güçlü, 2017; Toytok ve Doğan, 2019; Uğurlu, 2016; Üstün ve Bostanc1, 2021). Bu araştırmalardan farklı olarak, bu çalışmada kendine özgü yanları ile diğer okullardan farklılaşabilen mesleki ve teknik liselerde, informal iletişimi araştırmak, bu farklılıkların informal iletişime ne ölçüde yansıyıp yansımadığına dikkat çekmek ve bu manada literatüre katkı sunmak hedeflenmiştir.

\section{İletişim}

İletişim, insanlar arası ilişkilerde vazgeçilmez bir öğedir. Her türlü etkinlik, paylaşım, davranış, tavır ve tutum iletişim unsuru olarak kabul edilir (Uğurlu, 2014). İnsanoğlunun yaratılışından beri var olan iletişime yönelik onlarca iletişim tanımı yapılmıştır. Genel manada iletişim, bir bireyden diğer(ler)ine bilgi aktarma ve ortak bir anlayış oluşturma süreci (Lunenburg, 2010), bir bilginin bir birey ya da gruptan diğer birey ya da gruplara aktarılması (Riggio, 2016), insan davranışını değiştirmek amacıyla her türlü kavram ve sembolün iletilme süreci (Bursalığlu, 2012), bilgi üretme, anlamları ortak kılma ve anlamlandırma süreci şeklinde tanımlanabilmektedir (Uğurlu, 2014). İletişim, karar verme sürecinde seçenekleri belirlerken ve değerlendirirken birey ve gruplara ihtiyaç duydukları bilginin aktarılmasını sağlar (Robbins ve Judge, 2013). 


\section{Örgütsel İletişim}

İletişim örgütün can damarı gibi işlev gören ve sürekliliği olan bir süreçtir (Aydın, 2013; Bektaş ve Erdem, 2015; Riggio, 2016). Çünkü örgütlerde bilginin tüm birimlere zamanında ve çarpıtılmadan ulaştırılabilmesi, örgütün işleyişini sürdürebilmesi için hayati önemdedir (Aydın, 2013; Bektaş ve Erdem, 2015). Örgütsel iletişim; yazılı yada sözlü emirler, informal sohbetler, elektronik mesajlar, yazılı raporlar, duyuru panosundaki ilanlar, yöneticiler arası tartışmalar vs. pek çok şekilde gerçekleşebilir (Riggio, 2016). Örgütsel başarı ve etkililiğin elde edilmesinde önemli bir unsur olan örgütsel iletişim, örgütteki ilişkilerin sağlıklı bir şekilde sürdürülmesine katkıda bulunur. Bu nedenle de örgütsel manada vazgeçilmez olan iletişim, sağlıklı ve etkili bir örgüt iklimi oluşturma giden yolda kritik bir öneme sahiptir (Eğinli veBitirim, 2008). Örgütsel iletişim, bireyle örgüt arasında karşılıklı bilgi alışverişinin, bireyi motive etmenin, bireysel ve örgütsel hedeflere ulaşmanın, işgörenler ile yöneticiler arasında ortak bir anlayışıı temelini oluşturur (Karaçor ve Şahin, 2005). Bireyler, örgütlerinde diğer bireyler ve gruplarla iletişim kurma gereksinimi hissederler (Eğinli ve Bitirim, 2008; Kraunt vd., 2002; Mert, Bekmezci ve Eroğluer, 2019). Örgütsel iletişim, formal (biçimsel/resmi) ve informal (doğal/resmi olmayan) iletişim olmak üzere iki şekilde gerçekleşir (Bekmezci ve Eroğluer, 2019; Bektaş ve Erdem, 2015; Eğinli ve Bitirim, 2008; Kraunt vd., 2002). Bir örgütün hedeflerine ulaşmasında formal ve informal iletişim birlikte rol oynayarak birbirlerini tamamlarlar (Afat ve Arslan, 2019; Bursalığlu, 2012). Formal iletişim, daha çok örgütteki hiyerarşik yapıyla ilgilidir. Rasyonel ve planlanmış bilgi akışının sağladığ i iletileri kapsar. İnformal iletişim ise hiyerarşik yapının ötesinde, kişiler arası ilişkiler ağı yoluyla gerçekleşir. Örgütün informal yanını işletir (Gürsel, 2006).

\section{Örgütlerde İnformal İletişim}

İletişim, örgütteki işgörenlerin davranışlarını kontrol eder. Örgütlerde işgörenlerin uymak zorunda olduğu kurallar daha çok formal iletişim aracılığıyla kontrol edilir. İşgörenlerin mesleki faaliyetleriyle ilgili mesajlar yine formal iletişim kanallarıyla iletilir (Robbins ve Judge, 2013). Örgütsel iletişim, her zaman formal ve kontrol edilebilir bir biçimde oluşmamakta, örgüt içi bilginin yayılmasında formal iletişimin yanında informal iletişim kanalları da yaygın olarak kullanılmaktadır (Eğinli ve Bitirim, 2008). Bunun dışında kendi kendine oluşan, kişisel ve sosyal mesajların iletilmesinde rol oynayan informal iletişim kanalları da bulunmaktadır (Robbins ve Judge, 2013). İnformal iletişim, örgütlerde işgörenler arasında kendiliğinden ya da grupların ilgi alanlarına göre ortaya çıkar. İşgörenlerin kendi aralarındaki bakışları, mimikleri, jestleri ya da duruşları informal iletişime destek verir (Subramanian, 2006). İnformal iletişim de örgütlerde davranışları kontrol eder. Ancak daha çok işgörenlerin psikolojik 
ve sosyal ihtiyaçlarının karşılanabildiği, memnuniyetlerini ve hayal kırıklıklarını gösterebildikleri temel sosyal etkileşim kaynağıdır (Robbins ve Judge, 2013). İnformal iletişim, insanların fiziksel ve psikolojik yakınlık kurmaya, sosyalleşmeye veya bir gruba dâhil olmaya ihtiyaç duymaları nedeniyle (Ergen, 2011) plansız ve programsız bir şekilde, örgütün hiyerarşik yapısı dışında, işgörenlerin sosyal ve bilgi ihtiyaçlarından kendiliğinden doğar (Mert, Bekmezci ve Eroğluer, 2019; Uğurlu, 2014). Bu bilgiler göz önüne alındığında informal iletişimi; gönüllü, sosyal veya küçük gruplar arasında gerçekleşen iletişim olarak tanımlamak mümkündür (Fay ve Kline, 2012). Tanımdan da anlaşılacağı üzere informal iletişim örgütteki birey ve grupların etkileşiminde rol oynar. İnformal iletişim, doğası gereği daha esnek olması (Uğurlu, 2014), etkileşimli ve daha zengin içeriğe sahip olup formal iletişime göre daha baskın unsurlar içermesi (Kraunt vd., 2002) bakımından özellikle sosyal ilişkileri artırmada fark yaratabilir (Uğurlu, 2014).

\section{İnformal İletişimin Avantajları}

Bir örgütte işgörenler arasında işbirliği yapılabilmesi, güçlü bir iletişim gerektirir (Mert, Bekmezci ve Eroğluer, 2019). Bu güçlü iletişim ağının önemli bir boyutu olan informal iletişim kanallarıyla, örgüt üyeleri daha yaratıcı ve daha aktif davranmaya başlayabilirler (Fay ve Kline, 2012). İnformal iletişim, örgüt üyelerinin amaçlarını, değerlerini ve tutumlarını yansıtır. Örgüte yarar sağlayacak şekilde kullanıldığında etkililiği ve verimliliği arttırır (Toytok ve Doğan, 2019). İnformal iletişim, örgütsel problemin tartışılmasına ve kararların alınmasına etki eder, örgüt üyelerinin kendi duygularını rahatlıkla dile getirebilmelerine olanak sağlar, ait olma duygularını geliştirebilir (Subramanian, 2006). İşgörenlerin moralini yükseltmek, deneyimleri paylaşmak, yenilikleri öğrenmek ve aktarmak, işbirliği yapmak, fikir alışverişinde bulunmak ve değişen çevre şartları hakkında daha fazla bilgi edinmek amacıyla kullanıldığında örgüt için oldukça faydalıdır (Karcıoğlu, Timuroğlu ve Çınar, 2009). İnformal iletişim, etkili gerçekleştiğinde yöneticiler için de değerli bir yönetim kanalı haline gelebilir. Yöneticiler, formal iletişimle tamamlanamayan alanları kapsayacak politikalar geliştirerek informal iletişim kanallarını kullanabilir, örgütün etkililiği ve verimliliğine katkıda bulunabilirler (Arabac1, Sünkür ve Şimşek, 2012; Bektaş ve Erdem, 2015; Subramanian, 2006). Yöneticiler formal iletişim kanalları aracılığıyla elde edemedikleri bilgilere informal iletişim kanallarıyla ulaşabilirler. Bu da bilgilerin daha hızlı toplanmasını, dağıtılmasını ve bireyler arasında dayanışma kurulmasını sağlayarak, hızlı ve etkili karar vermeye yardımcı olabilir (Subramanian, 2006). Ayrıca informal iletişim, örgüt üyelerinin hem örgütle ilgili hem de diğer bireysel ve sosyal gereksinimlerini karşıladığından, formal iletişimden daha verimli olabilmektedir (Mert, Bekmezci ve Eroğluer, 2019). İnformal iletişim, formal iletişimin yükünü hafifletmek, örgüt içinde hızlı bilgi akışına imkan vermek, birlik ve beraberliği geliştirmek, işgörenlerin 
motivasyonunu arttırmak ve ekip çalışmalarını aktif hale getirmek gibi katkılar sağlar (Bektaş ve Erdem, 2015). Neticede informal iletişimin avantajlarının azımsanmayacak kadar fazla olduğunu söylemek mümkündür (Subramanian, 2006).

\section{İnformal İletişimin Dezavantajları}

Örgütsel iletişim, bazen informal iletişim kanallarıyla kontrolden çıkarak problemli ve tehlikeli bir yapıya bürünebilir. Örgüt üyeleri arasındaki işbirliği ve dayanışma zedelenebilir, performansta düşüş yaşanabilir (Bektaş ve Erdem, 2015; Eğinli ve Bitirim, 2008). Örgütün bazı üyeleri, informal iletişim kanalları aracılığıla kendi çıkarlarına yönelik kazanımlar sağlamak isteyebilirler. İnformal iletişim yoluyla samimiyet ve yakınlık elde eden üyeler, kendilerine olumsuz yansımaları olabilecek durumlarda rasyonel ve yapıcı olmaktan ziyade duygusal ve yıkıcı olabilirler. Örgütlerde, özellikle dedikodu ve söylenti gibi negatif iletişim öğelerinin ortaya çıkmasında ve sürdürülmesinde etkili olan informal iletişim kanallarını tamamen ortadan kaldırmak mümkün olmayabilir. Ancak informal iletişimin negatif etkilerini azaltmanın hatta önlemenin mümkün olduğu söylenebilir. Bu noktada dikkat edilmesi gereken husus, dedikodu ve söylentilerin örgütte yayılmasının önemsenmemesi durumudur. Bu durumda informal iletişim çoğu zaman zehirli bir yapıya bürünerek kişilerarası ilişkilere zarar vermekte ve örgüte yönelik olumsuz sonuçların doğmasına neden olabilmektedir. Örgütteki birçok farklı öğeden etkilenen iletişim olgusu, kontrolden çıkarak daha çok dedikodu ve söylentiler ile beslendiğinde örgütteki entelektüel güvenliği zedeler. Böyle bir durumda örgütte zehirli (toksik) ilişkiler ortaya çıkmakta, oluşan sağlıksız bir iletişim ortamı örgüt iklimini olumsuz etkilemektedir (Eğinli ve Bitirim, 2008).

\section{Eğitim Örgütlerinde İletişim}

İnsanın bulunduğu tüm yapılarda informal etkileşimlerin oluşmasının kaçınılmaz olması nedeniyle, örgütlerde formal iletişim kanallarıyla birlikte kendiliğinden oluşan informal iletişim kanallarının da bulunduğu çalışmanın başında ifade edilmişti. Bu informal etkileşimler örgütün kültürünü, iklimini, derin, duygusal ve dramatik yönlerini yansıtır (Toytok ve Doğan, 2019). Eğitim örgütleri; öğrenci, öğretmen, yönetici ve diğer paydaşlar arasında yoğun iletişim yaşanması (Afat ve Arslan, 2019), yapı ve özelliklerinin farklılaşması nedeniyle informal iletişimin formal iletişimden daha fazla rol oynadığ görülebilir (Bursalığlu, 2012). Eğitim örgütlerinde yönetici, öğretmen, öğrenci ve velilerin birbirlerine karşı eylemleri tamamıyla iletişimsel eylemlerdir. Girdisi ve çıktısı insan olan eğitim örgütlerinde, iletişim ve insan ilişkileri diğer örgütlere göre daha önemlidir (Bolat, 1996; Güçlü, 2017). Eğitim örgütlerinin insan ilişkilerinin yaygın olduğu örgütler olması, bu ilişkilerin de doğas1 gereği daha 
çok informal iletişim yoluyla gerçekleştiği göz önüne alındığında (Hoy ve Miskel, 2010) eğitim faaliyetlerinin amacına ulaşabilmesi için öğrenci, öğretmen, okul yöneticisi ve diğer paydaşların etkili iletişim kurabilmeleri gerekmektedir (Ay ve Uğurlu, 2016). İnformal iletişimin okullarda fikirlerin özgürce ifade edilmesini sağladığı, okul kültürünü güçlendirdiği, sosyalliği arttırdığı, etkililiğe katk1 sağladığı (Himmetoğlu, Ayduğ ve Bayrak, 2020), paydaşlar arası motivasyon iş birliğini sağlayarak okulun amaçlarına ulaşmasına yardımcı olduğunu söylemek mümkündür (Afat ve Arslan, 2019).

Mesleki ve teknik eğitim kurumları plan, program, çalışma ortamı, aynı fiziki ortamda farklı bölümlerin bulunması, öğrenimin bir bölümünün iş örgütlerinde uygulama şeklinde olması nedeniyle gelişen çevre ilişkileri, öğrencilerin, velilerin, çevrenin beklentileri bakımından genel ortaöğretim kurumlarından farklılaşmaktadır. Bu farklı öğelerin senteziyle mesleki ve teknik eğitim yapan okullarda kendine has bir örgüt kültürünün mevcut olduğu söylenebilir (Sönmez, 2006). Ayrıca, mesleki ve teknik liselerin, öğrencilerin çoğunlukla istemeyerek geldikleri, düşük motivasyonla birlikte düşük akademik başarı gösterdikleri, tercih edilme oranının az olduğu, toplumun ve öğretmenlerin okula olan bakış açılarının nispeten olumsuz olduğu okullar olarak algılandıkları da bilinmektedir (Atalay Mazlum ve Balcı, 2018). Bu bağlamda mesleki ve teknik liselerde informal iletişim kanallarının kullanımının araştırılmaya değer olduğu, bu okullarda görev yapmakta olan yönetici ve öğretmenlerin informal iletişimi kullanma düzeylerinin ve informal iletişimin çeşitli değişkenlere göre araştırılmasının alanyazına katkı sağlayacağı, bu durumla ilgili mevcut boşluğu doldurmada bir adım olabileceği söylenebilir.

$\mathrm{Bu}$ araştırmanın amacı mesleki ve teknik liselerde görev yapmakta olan yönetici ve öğretmenlerin informal iletişimi kullanma düzeylerini ortaya koyarak, informal iletişimin çeşitli değişkenlere göre farklılaşıp farklılaşmadığını tespit etmektir. $\mathrm{Bu}$ temel amaç çerçevesinde aşağıdaki sorulara cevap aranmıştır:

1- Mesleki ve teknik liselerde görev yapmakta olan yönetici ve öğretmenlerin kullandıkları informal iletişim hangi düzeydedir?

2- Mesleki ve teknik liselerde görev yapmakta olan yönetici ve öğretmenlerin kullandıkları informal iletişim çeşitli değişkenlere göre (cinsiyet, yaş, kıdem, okuldaki çalışma süresi, görev türü, okuldaki öğretmen sayısı, öğrenim durumu ve mezun olunan fakülte) anlamlı düzeyde farklılaşmakta midır?

Araştırmanın amacı ve problem durumuna paralel olacak şekilde değinilen literatürün ardından, sonraki bölümlerde araştırmanın yöntemi, bulguları, tartışma, sonuç ve önerilere yer verilmiştir. 


\section{YÖNTEM}

\section{Araştırmanın Modeli}

Mesleki ve teknik liselerde görev yapmakta olan yönetici ve öğretmenlerin informal iletişimi kullanma düzeylerini ortaya koyarak, informal iletişimin çeşitli değişkenlere göre farklılaşıp farklılaşmadığını tespit etmenin amaçlandığ 1 bu araştırmada nicel araştırma yöntemlerinden olan betimsel tarama modeli kullanılmıştır. Betimsel tarama modeli; daha fazla katılımcı ile araştırma yapmaya uygun ve katılımcıların bir konu hakkındaki yönelimlerini ve tutumlarını ortaya çıkarmayı hedefleyen bir araştırma modelidir (Büyüköztürk, Kılıç, Akgün, Karadeniz ve Demirel, 2017).

\section{Araştırmanın Evreni ve Örneklemi}

Araştırmanın evrenini mesleki ve teknik liselerde görev yapan öğretmen ve yöneticiler oluşturmaktadır. Evren 612 öğretmen ve yöneticiden oluşmaktadır. $\mathrm{Bu}$ genişlikteki evren için gereken örneklem sayısının en az 237 kişi olması gerektiği hesaplanmış olup evreni temsilen kolayda örnekleme yoluyla ulaşılan örneklem Kahramanmaraş Onikişubat ilçesinde bulunan mesleki ve teknik liselerde görev yapan 337 öğretmen ve yöneticiden oluşmaktadır. Verileri toplamadan once etik kurul onayı alınmıştır. Ayrıca araştırmanın her aşamasında etik değerlere özen gösterilmiştir. Ayrıca araştırmanın sadece mesleki ve teknik liselerde görev yapmakta olan yönetici ve öğretmenlerin katılımıyla gerçekleşmesi bir sınırlılık olarak görülmektedir. Katılımcılarla Araştırmaya katılanlara ait demografik bilgiler Tablo 1'de gösterilmiştir.

Tablo 1. Katılımcılara İlişkin Demografik Bilgiler

\begin{tabular}{|c|c|c|c|}
\hline Kategoriler & Gruplar & $f$ & $\%$ \\
\hline \multirow[t]{2}{*}{ Cinsiyet } & Kadın & 196 & 58,2 \\
\hline & Erkek & 141 & 41,8 \\
\hline \multirow[t]{4}{*}{ Yaş } & 30 ve altı & 76 & 22,6 \\
\hline & $31-35$ yaş & 75 & 22,3 \\
\hline & $36-40$ yaş & 68 & 20,2 \\
\hline & 41 ve üzeri & 118 & 35,0 \\
\hline \multirow[t]{5}{*}{ Mesleki Kıdem } & $0-5$ y1l & 115 & 34,1 \\
\hline & $6-10$ y1l & 67 & 19,9 \\
\hline & $11-15$ y1l & 37 & 11,0 \\
\hline & $16-20 \mathrm{y} 11$ & 56 & 16,6 \\
\hline & 21 yıl ve üzeri & 62 & 18,4 \\
\hline Okuldaki & $0-5$ y1l & 228 & 67,7 \\
\hline Çalışma Süresi & $6-10$ y1l & 72 & 21,4 \\
\hline
\end{tabular}




\begin{tabular}{|c|c|c|c|}
\hline & 11 yıl ve üzeri & 37 & 11,0 \\
\hline Görev Türü & $\begin{array}{l}\text { Öğretmen } \\
\text { Yönetici }\end{array}$ & $\begin{array}{r}306 \\
31\end{array}$ & $\begin{array}{r}90,8 \\
9,2\end{array}$ \\
\hline $\begin{array}{c}\text { Okuldaki } \\
\text { Öğretmen } \\
\text { Sayısı }\end{array}$ & $\begin{array}{l}30 \text { ve alt1 } \\
31-35 \\
36-40 \\
41 \text { ve üzeri }\end{array}$ & $\begin{array}{r}55 \\
28 \\
43 \\
211\end{array}$ & $\begin{array}{r}16,3 \\
8,3 \\
12,8 \\
62,6\end{array}$ \\
\hline $\begin{array}{l}\text { Öğrenim } \\
\text { Durumu }\end{array}$ & $\begin{array}{l}\text { Lisans } \\
\text { Lisansüstü }\end{array}$ & $\begin{array}{r}280 \\
57\end{array}$ & $\begin{array}{r}83,1 \\
16,91\end{array}$ \\
\hline Mezuniyet & $\begin{array}{l}\text { Eğitim Fakültesi } \\
\text { Fen Edebiyat Fakültesi } \\
\text { Diğer } \\
\text { Toplam }\end{array}$ & $\begin{array}{r}166 \\
74 \\
97 \\
337 \\
\end{array}$ & $\begin{array}{r}49,3 \\
22.0 \\
28,8 \\
100,0\end{array}$ \\
\hline
\end{tabular}

Tablo 1'de görüldüğü üzere araştırmaya katılanların 196's1 $(\% 58,2)$ kadın, 141 'i $(\% 41,8)$ erkek; 76'sı $(\% 22,6) 30$ yaş veya altında, 75 'i (\%22,3) 31-35 yaş arasında, 68'i $(\% 20,2)$ 36-40 yaş arasında, 118'i $(\% 35,0)$ ise 41 yaş ve üzerindedir. Mesleki kıdem açısından 0-5 yıl kıdeme sahip olanlar $115(\% 34,1)$, 6-10 y1l k1deme sahip olanlar 67 (\%19,9), 11-15 y1l kıdeme sahip olanlar 37 (\%11,0), 16-20 y1l k1deme sahip olanlar $56(\% 16,6), 21$ yıl ve üzeri k1deme sahip olanlar $62(\% 18,4)$ katılımcı olarak görülmektedir. Katılımcıların 228'i $(\% 67,7)$ 0-5 y11, 72'i (\%21,4) 6-10 yıl ve 37'si (\%11,0) 11 yıl ve üzeri süredir aynı okulda çalışmaktadır. Katılımcıların 306'sı (\%90.8) öğretmen, 31'i (\%9,2) yöneticidir. 55 katılımcının okulunda $(\% 16,3) 30$ veya altında öğretmen, 28 katılımcının okulunda $(\% 8,3)$ 31-35 arası ögretmen, 43 katılımcının okulunda $(\% 12,8)$ 36-40 arası öğretmen ve 211 katılımcının okulunda $(\% 62,6) 41$ veya üzeri öğretmen bulunmaktadır. Kat1lımcılardan 280'i $(\% 83,1)$ lisans mezunu iken, 57'si $(\% 16,91)$ ise lisansüstü eğitim almışlardır. 166 katılımcının $(\% 49,3)$ eğitim fakültesi mezunu, 74 katılımcının (\%22,0) eğitim fakültesi mezunu iken 97 katılımcının $(\% 28,8)$ diğer fakültelerden mezun oldukları görülmektedir.

\section{Veri Toplama Araçları}

$\mathrm{Bu}$ araştırmada katılımcılara iki form sunulmuştur. Formlardan ilki, araştırmaya katılan mesleki ve teknik lise öğretmen ve yöneticilerinin demografik özelliklerini belirlemeye yönelik olarak hazırlanan Kişisel Bilgiler Formu'dur. Kişisel bilgiler formunda cinsiyet, yaş, mesleki kıdem, okuldaki çalış süresi, görev türü, okuldaki öğretmen sayısı, öğrenim durumu ve mezun olunan fakülte ile ilgili sorular yer almaktadır. Diğer formda ise Toytok ve Doğan (2019) 
tarafından geliştirilen Okullarda İnformel İletişsim Ölçeği (OİIÖ) yer almaktadır. Ölçek 5 boyut ve 23 maddeden oluşan beşli Likert tipi bir ölçektir. Ölçekteki puanları yorumlamada $(5-1=4 ; 4 / 5=0,80)$ hesaplaması yapılarak aralıklar belirlenmiştir. Buna göre; 1,00-1,80 aralığ 1 hiçbir zaman, 1,81-2,60 aralı̆̆ 1 nadiren, 2,61-3,40 aralığ 1 ara sira, 3,41-4,20 aralığ1 çoğu zaman, 4,21-5,00 aralığı her zaman olacak şekilde düzenlenmiştir. Cronbach's Alpha iç tutarlılık katsayılarının Toytok ve Doğan (2019) tarafindan yapılan çalışmada alt boyutlar kapsamında .69 ile .82 arasında değiştiği, bu araştırmada ise ölçeğin genelinde .84 olarak tespit edilmiştir. Büyüköztürk vd. (2010)'ne göre Cronbach's Alpha iç tutarlılık katsayılarının 0,70 'in üzerinde olmasının güvenirlik için yeterli bir ölçüt olduğu göz önüne alınırsa bu değerin kabul edilebilir olduğunu söylemek mümkündür.

\section{Veri Analiz Yöntemi}

Verilerin analizinde SPSS 26.0 programı kullanılmıştır. Okul yöneticileri ve öğretmenlerin informal iletişim algı düzeylerini tespit etmede aritmetik ortalama, standart sapma gibi betimleyici istatistiksel bilgilerinden faydalanılmıştır. Bununla birlikte katılımcılara ilişkin kişisel özelliklerin açıklanmasında frekans ve yüzde kullanılmıştır. Analizlerden önce verilerin normal dağılıma sahip olup olmadığının kontrolü yapılmıştır. Ölçekte her bir değişkenin grupları için verilerin basıklık (Skewness) - çarpıklık (Kurtosis) değerleri incelenmiş, basıklık değerinin -.162, çarpıklık değerinin -.195 olduğu tespit edilmiştir. Basıklık ve çarpıklık değerlerinin -1.5 ile +1.5 arasında olmasının normalliği sağladığ 1 kabulü göz önüne alındığında bu araştırmanın verilerine ait dağılımın normal olduğunu söylemek mümkündür (Can, 2017). Normallik testlerinde $p=0,05$ düzeyinde anlamlılık dikkate alındığında $p>0,05$ olarak tespit edilmiştir. $\mathrm{Bu}$ durum, normallik varsayımına uygun olmaktadır. Normallik testi bulguları göz önüne alınarak, değişkenlerin analizinde parametrik analiz yöntemleri kullanılmıştır. Araştırmanın alt problemleri doğrultusunda ikili grupların olduğu analizlerde parametrik testlerden bağımsız örneklemler t-Testi; ikiden fazla grubun olduğu değişkenler ile gerçekleştirilen analizlerde parametrik testlerden tek yönlü varyans analizi (ANOVA) testi yapılmıştır. ANOVA testindeki anlamlı farklılıkların çıktığında farkın kaynağını tespit edebilmek amacıyla Post Hoc analizlerinden Tukey testi yapılmıştır. Verilerin analizinde anlamlılık düzeyi için $p=0,05$ olarak ele alınmıştır.

\section{BULGULAR}

Mesleki ve teknik liselerde görev yapmakta olan yönetici ve öğretmenlerin informal iletişimi kullanma düzeyleri ile informal iletişimin çeşitli değişkenlere göre farklılaşıp farklışamadığına yönelik bulgular Tablo 2'de yer almaktadır. 
Tablo 2. Mesleki ve Teknik Liselerde görev yapan Öğretmen ve Yöneticilerin İnformal İletişim Algılarına İlişkin Betimleyici İstatistiksel Bilgileri

\begin{tabular}{lccccc}
\hline Ölçek & \multirow{2}{*}{$\overline{\boldsymbol{N}}$} & $\overline{\boldsymbol{X}}$ & Ss & \multicolumn{2}{c}{ \%95 Güven } \\
\cline { 5 - 6 } & & & Alt Sınır & Üst Sınır \\
\hline $\begin{array}{l}\text { Okullarda } \\
\text { Informal İletişim }\end{array}$ & 337 & 2,86 & 0,49 & 1,52 & 4,48 \\
\hline
\end{tabular}

Tablo 2'de yer alan bulgulara göre katılımcıların okullarında informal iletişimin kullanılmasına yönelik algılarına ait ortalamanın 2.86 olduğu, bu değerin ara sıra düzeyine karşl1ık geldiği belirlenmiştir.

Tablo 3. Bazı Değişkenlere Göre Katılımcıların Okullardaki İnformal İletişim Algılarına t-Testi Sonuçları

\begin{tabular}{lccccccc}
\hline Değişken & & $\boldsymbol{n}$ & $\overline{\boldsymbol{X}}$ & SS & $\boldsymbol{t}$ & sd & $\boldsymbol{p}$ \\
\hline \multirow{2}{*}{ Cinsiyet } & Kadın & 196 & 2,85 & 0,50 &,- 531 & 335 & 0,596 \\
& Erkek & 141 & 2,88 & 0,49 & & & \\
\hline \multirow{2}{*}{ Görev Türü } & Öğretmen & 306 & 2,86 & 0,50 &,- 141 & 335 & 0,109 \\
& Yönetici & 31 & 2,87 & 0,40 & & & \\
\hline \multirow{2}{*}{ Ŏgrenim } & Lisans & 280 & 2,86 & 0,50 &,- 518 & 335 & 0,580 \\
Durumu & Lisansüstü & 57 & 2,89 & 0,45 & & & \\
\hline
\end{tabular}

${ }^{*} p<0,05$

Tablo 3’te cinsiyet, görev türü ve öğrenim durumu değişkenlerine göre katılımcıların okullardaki informal iletişim algı düzeylerine ilişkin t-Testi sonuçları yer almaktadır. $\mathrm{Bu}$ üç değişkene göre anlamlı bir fark bulunmamaktadır. Tablo 4'te yaş değişkenine göre araştırmaya katılan öğretmen ve yöneticilerin okullardaki informal iletişim algılarına ilişkin ANOVA testi sonuçları verilmiştir.

Tablo 4. Yaş Değişkenine Göre Araştırmaya Katılan Öğretmen ve Yöneticilerin Okullardaki İnformal İletişim Algılarına İlişkin ANOVA Testi Sonuçları

\begin{tabular}{|l|l|c|c|c|c|c|c|c|c|c|c|}
\hline Değişken & & $\boldsymbol{n}$ & $\overline{\boldsymbol{X}}$ & Ss & $\begin{array}{c}\text { Varyansın } \\
\text { Kaynağı }\end{array}$ & $\begin{array}{c}\text { Kareler } \\
\text { Toplamı }\end{array}$ & sd & $\begin{array}{c}\text { Kareler } \\
\text { ort. }\end{array}$ & $\boldsymbol{F}$ & $\boldsymbol{p}$ & Fark \\
\hline Yaş & $\begin{array}{l}30 \text { veya } \\
\text { altı (1) }\end{array}$ & 76 & 2,80 & 0,52 & $\begin{array}{c}\text { Gruplar } \\
\text { aras1 }\end{array}$ & 0,661 & 3 & 0,220 & 0,888 & 0,448 & - \\
\cline { 2 - 10 } & $\begin{array}{l}31-35 \\
(2)\end{array}$ & 75 & 2,83 & 0,50 & Grup içi & 82,618 & 333 & 0,248 & & & \\
\cline { 2 - 10 } & $\begin{array}{l}36-40 \\
(3)\end{array}$ & 68 & 2,91 & 0,47 & Toplam & & & & & & \\
\cline { 2 - 10 } & $\begin{array}{l}\text { 41veya } \\
\text { üstü (4) }\end{array}$ & 118 & 2,89 & 0,48 & & & & & & & \\
\hline
\end{tabular}




\begin{tabular}{|c|c|c|c|c|c|c|c|c|c|c|c|}
\hline \multirow[t]{5}{*}{$\begin{array}{l}\text { Mesleki } \\
\text { Kıdem }\end{array}$} & $0-5(1)$ & 115 & 2,72 & 0,53 & $\begin{array}{c}\text { Gruplar } \\
\text { aras1 }\end{array}$ & 4,06 & 4 & 1,015 & 4,254 & 0,002 & $1-3$ \\
\hline & $6-10(2)$ & 67 & 2,90 & 0,48 & Grup içi & 79,218 & 332 & 0,239 & & & \\
\hline & $\begin{array}{l}11-15 \\
(3)\end{array}$ & 37 & 2,94 & 0,44 & Toplam & 83,278 & 336 & & & & \\
\hline & $\begin{array}{l}16-20 \\
(4)\end{array}$ & 56 & 3,01 & 0,39 & & & & & & & \\
\hline & $\begin{array}{l}21 \mathrm{y} 11+ \\
(5)\end{array}$ & 62 & 2,91 & 0,49 & & & & & & & \\
\hline \multirow{3}{*}{$\begin{array}{l}\text { Okulda } \\
\text { Çalışılan } \\
\text { Süre }\end{array}$} & $\begin{array}{ll}0-5 & \text { y1l } \\
(1) & \\
\end{array}$ & 228 & 2,80 & 0,50 & $\begin{array}{l}\text { Gruplar } \\
\text { aras1 }\end{array}$ & 2,920 & 2 & 1,460 & 6,069 & 0,003 & $1-2$ \\
\hline & $\begin{array}{l}6-10 \quad \text { y1l } \\
(2)\end{array}$ & 72 & 3,00 & 0,43 & Grup içi & 80,358 & 334 & 0,241 & & & \\
\hline & $\begin{array}{l}11 \mathrm{y} 1 \mathrm{l}+ \\
\text { (3) }\end{array}$ & 37 & 3,00 & 0,51 & Toplam & 83,278 & 336 & & & & \\
\hline \multirow{3}{*}{$\begin{array}{l}\text { Okuldaki } \\
\text { Öğretmen } \\
\text { Sayısı }\end{array}$} & $\begin{array}{l}30 \text { ve } \\
\text { alt1 (1) }\end{array}$ & 55 & 2,86 & 0,49 & $\begin{array}{l}\text { Gruplar } \\
\text { aras1 }\end{array}$ & ,647 & 2 & ,216 & ,869 & 0,458 & - \\
\hline & $\begin{array}{l}31-35 \\
(2)\end{array}$ & 28 & 2,78 & 0,53 & Grup içi & 82,631 & 334 & ,248 & & & \\
\hline & $\begin{array}{l}36-40 \\
\text { (3) }\end{array}$ & 43 & 2,78 & 0,56 & Toplam & 83,278 & 336 & & & & \\
\hline \multirow{3}{*}{$\begin{array}{l}\text { Mezun } \\
\text { Olunan } \\
\text { Fakülte }\end{array}$} & $\begin{array}{l}\text { Eğitim } \\
\text { (1) }\end{array}$ & 166 & 2,94 & 0,49 & $\begin{array}{l}\text { Gruplar } \\
\text { aras1 }\end{array}$ & 2,934 & 2 & 1,467 & 6,099 & 0,003 & $1-2$ \\
\hline & $\begin{array}{l}\text { Fen } \\
\text { Edebiyat } \\
(2)\end{array}$ & 74 & 2,70 & 0,55 & Grup içi & 80,344 & 334 & ,241 & & & \\
\hline & $\begin{array}{l}\text { Diğer } \\
\text { (3) }\end{array}$ & 97 & 2,86 & 0,41 & Toplam & 83,278 & 336 & & & & \\
\hline
\end{tabular}

${ }^{*} \mathrm{p}<0,05$

Tablo 4'te yaş, mesleki kıdem, okulda çalışılan süre, okuldaki öğretmen sayısı ve mezun olunan fakülte değişkenlerine göre katılımcıların okullarda informal iletişim düzeylerinin anlamlı bir düzeyde farklılık oluşturup oluşturmadığının analiz sonuçları bulunmaktadır. Tabloda görüldüğ̈̈ üzere mesleki kıdem, okulda çalışılan süre ve mezun olunan fakülte değişkenlerine göre anlamlı farklılık bulunduğu tespit edilmiştir. Yapılan Tukey testine göre mesleki kıdemle ilgili farkın mesleki kıdemi 0-5 yıl olanlar ile 16-20 yıl olanlar arasında olduğu tespit edilmiştir. Mesleki kıdemi 11-15 yıl olanların informal iletişimi kullanma düzeyleri mesleki kıdemi 0-5 yıl olanlara göre daha yüksektir. Okulda çalışılan süre bakımından okulda çalışma süresi 0-5 yıl olanlar ile 6-10 yıl olanlar arasında anlamlı farklılık bulunduğu tespit edilmiştir. Okulda çalışma süresi 6-10 yıl olanların informal iletişimi kullanma düzeyleri okulda çalışma süresi 0-5 y1l olanlara göre daha yüksektir. Son olarak mezun olunan fakülte ile ilgili Eğitim Fakültesi mezunları ile Fen Edebiyat Fakültesi mezunları arasında anlamlı farklılık bulunduğu ortaya çıkmıştır. Eğitim Fakültesi mezunlarının informal iletişimi kullanma düzeyleri Fen Edebiyat Fakültesi mezunlarına göre daha yüksektir. 


\section{TARTIŞMA}

$\mathrm{Bu}$ araştırma, mesleki ve teknik liselerde görev yapmakta olan yönetici ve öğretmenlerin informal iletişimi kullanma düzeylerini ortaya koyarak, informal iletişimin çeşitli değişkenlere göre farklılaşıp farklılaşmadığını tespit etmek amacıyla gerçekleştirilmiştir. Araştırmada ilk olarak mesleki ve teknik liselerde görev yapmakta olan okul yöneticileri ve öğretmenlerin informal iletişim alg1 düzeylerinin ara sıra (orta) düzeyinde olduğu tespit edilmiştir. Üstün ve Bostanc1 (2021), Afat ve Arslan (2019), Ay ve Uğurlu (2016) araştırmalarında öğretmenlerin okullarındaki informal iletişimin düzeyine ilişkin algılarının yüksek düzeyde olduğu bulgusuna ulaşmışlardır. $\mathrm{Bu}$ araştırmaların gerçekleştirildikleri evrenlerin ilkokul, ortaokul ve liseler olduğu dikkate alındığında, mesleki ve teknik liseler gibi kendine has işleyişi ve kültürü olan okullarda informal iletişimin nispeten düşük düzeyde olması dikkat çekicidir. Bu durum, aynı okul içinde farklı birimlerin olması ve bu birimler arası iletişimin zayıf olabileceği, çalışmanın kuramsal çerçevesinde de değinildiği gibi bu okullarda görev yapmakta olan yönetici ve öğretmenlerin olumsuz tutumlarının olabileceği ile açıklanabilir. İnformal iletişimin örgütsel iletişimin önemli bir boyutu olduğu sık sık dile getirilmektedir (Himmetoğlu, Ayduğ ve Bayrak, 2020; Crampton, Hodge, ve Mishra, 1998; Kraunt vd., 1990). Örgüt üyeleri birbirleriyle kurdukları informal iletişimle birlikte, daha yaratıcı ve daha aktif davranmaya başlayabilirler (Fay ve Kline, 2012). Okulların, insan ilişkilerinin yaygın olduğu örgütler olduğu, informal iletişimin okullarda daha çok tercih edildiği bilinmektedir. İnformal iletişim, performansı arttırmanın yanında fikirlerin özgür bir biçimde ifade edilmesini, güvenliği, güçlü bir okul kültürünün oluşumunu ve gelişimini sağlar (Himmetoğlu, Ayduğ ve Bayrak, 2020; Hoy ve Miskel, 2010 ). İnformal iletişim ağları okullarda, bilginin dolaşımını destekleyerek formal düzene yardımcı olmakla birlikte informal gereksinimleri de karşılayabilir (Uğurlu, 2014). Okulda, informal ilişkilerin geliştirilmesiyle aile ortamı oluşur, ben yerine biz duygusu hakim olur, yardımlaşma ve motivasyon artar (Afat ve Arslan, 2019; Bursalıoğlu, 2012; Memduhoğlu ve Saylık, 2012). Öte yandan, Lohman (2006), öğretmenlerin meslekleriyle veya görev yaptıkları okulla ilgili birtakım bilgilere ihtiyaç duyduklarında internetten arama yapmak ve profesyonel yayınlara bakmak yerine daha çok meslektaşlarına sormak ve öğretmenler odası, öğlen araları ve ders araları gibi ortak mekan ve zamanlarda etkileşime geçerek bu ihtiyaçlarını karşılama eğiliminde olduklarını ifade etmektedir. Mesleki ve teknik liselerdeki farklı bölümlerin yer almasının bu etkileşimi, dolayısıyla da informal iletişimi sınırlayabileceği ileri sürülebilir. $\mathrm{Bu}$ okullar plan, program, çalışma ortamı, aynı fiziki ortamda farklı bölümlerin bulunması, çevre ilişkileri ve beklentiler bakımından genel ortaöğretim kurumlarından farklılaşmaktadır. Bu farklı öğelerin senteziyle mesleki ve teknik eğitim yapan okullarda kendine has bir örgüt kültürünün mevcut olduğu söylenebilir (Sönmez, 2006). Bu farklılıkların okuldaki iletişim ve araştırmanın 
bulgusundan hareketle informal iletişim düzeyinin de farklılaşabileceği, diğer okullara göre informal iletişimin daha düşük düzeyde gerçekleşebileceği söylenebilir.

Araştırmada ortaya çıkan diğer bulgu mesleki ve teknik liselerde görev yapmakta olan okul yöneticileri ve öğretmenlerin informal iletişim düzeylerinin mesleki kıdeme göre farklı1ık gösterdiği bulgusudur. Mesleki kıdemi 0-5 yıl arasında olanlar ile 11-15 yıl arasında olan katılımcıların örgütsel iletişim düzeyleri anlamlı biçimde farklılaşmaktadır. Mesleki kıdemi 11-15 yıl arasında olanlar, mesleki kıdemi 0-5 yıl arasında olanlara göre daha yüksek düzeyde informal iletişim düzeyine sahiptirler. Üstün ve Bostanc1 (2021), ilkokul, ortaokul ve lise öğretmenlerinin katılımıyla gerçekleştirdiği araştırmalarında, öğretmenlerin okullarındaki informal iletişimin mesleki kıdem değişkenine göre anlamlı farklılık göstermediği bulgusunu elde etmişlerdir. Bu farklılık mesleki ve teknik liseler ile diğer okullar arasındaki farklılıklardan kaynaklanabilir. Araştırmanın kuramsal çerçevesinde de değinildiği üzere mesleki ve teknik liselerin işleyişinin farklı olması, farklı bir kültürün mevcut olması okul yöneticileri ve öğretmenleri meslek hayatlarının ilk yıllarında daha fazla iletişim kurmaya, bilgi edinmeye ve dolayısıyla da informal iletişim kanallarını daha fazla kullanmaya sevk edebilir. Bununla birlikte Üstün ve Bostancı'nın araştırmalarında örgütsel iletişimin bilgi boyutunda 1-10 yıl arasında mesleki kıdeme sahip öğretmenler ile 21 yıl ve üzeri mesleki kıdeme sahip öğretmenler arasında olduğu bulgusu ortaya çıkmıştır. Mesleki kıdemi 1-10 yıl arasında mesleki kıdeme sahip öğretmenlerin 21 yıl ve üzeri mesleki kıdeme sahip öğretmenlere göre informal iletişimin bilgi boyutundaki algıları daha yüksektir. Üstün ve Bostancı, öğretmenlerin mesleğin ilk yıllarında kendilerini yenilediklerini, idealist olma eğiliminin bu yıllarda daha fazla olabileceğinden daha fazla öğrenme ihtiyacı hissedebilecekleri, daha heyecanlı olabilecekleri ve daha az tükenmişlik yaşayabileceklerini bu nedenlerle de informal iletişim kanallarını daha sık kullanabileceklerini ifade etmektedirler. Bu bulguya paralel şekilde, Afat ve Arslan (2019) öğretmenlerin informal iletişim düzeylerinin yaşa göre anlamlı biçimde farklılaştı̆̆ını, bu farklılı̆̆ın yaşları 26-30 arasında olan öğretmenler ile yaşları 41 veya üzerinde olan öğretmenler arasında olduğu bulgusunu elde etmişlerdir. 26-30 arası yaşlarda olan öğretmenleri informal iletişim kullanma düzeylerinin daha yüksek olduğu belirlenmiştir. Afat ve Arslan bu bulguyu, 26-30 yaşlarında olan öğretmenlerin bekar olma veya çocuk sahibi olmama ihtimallerinin 41 ve üzeri yaştakilere göre daha fazla olabileceği, bu durumun da okulda daha fazla vakit geçirmelerini ve okul dışı etkinliklere daha fazla katılımlarını sağlayabileceği ile açıklamışlardır. Araştırmanın bu bulgusu ve ilgili görüşler dikkate alındığında, göreve yeni başlayan öğretmenlerin nispeten idealist olmaları, daha fazla öğrenme ihtiyacı hissetmeleri, okulda daha fazla vakit geçirmeleri ve enerjilerinin yüksek olması gibi nedenlerle informal 
iletişimi daha fazla kullandıkları söylenebilir. Mesleki ve teknik liseler özelinde de bu görüşlerin geçerli olduğunu söylemek mümkündür.

Araştırmada mesleki ve teknik liselerde görev yapmakta olan okul yöneticileri ve öğretmenlerin informal iletişim algılarının okulda çalışılan süreye göre farklılık gösterdiği, bu farklılı̆̆ın okulda çalışılan süresi 0-5 yıl arasında olanlar ile 6-10 yıl arasında olduğu bulgusu ortaya çıkmıştır. Okulda çalışma süresi 6-10 yıl arasında olanların çalışma süresi 0-5 yıl olanlara göre informal iletişim algıları daha yüksek düzeydedir. Toytok ve Doğan (2019), resmi örgütlerin hemen hemen hepsinde formal iletişim kanallarının yanında informal iletişim kanallarının da bulunduğunu, örgüt üyelerinin etkileşimleri ile zamanla bu durumun kaçınılmaz olduğunun altını çizmektedirler. Buradan hareketle bir okulda çalışırken, ilk yıllarda informal iletişim kanallarının kullanımının daha az olabileceği, yaygınlaşmasının zaman alabileceği söylenebilir. Bu bulgunun öngörülebilecek bir bulgu olduğunu söylemek mümkündür. İnformal iletişim kanallarının kullanımının zaman istediği, bir örgütte veya bu araştırma özelinde bir okulda uzun süre çalışmanın informal iletişim kanallarının kullanılmasına zemin hazırladığı söylenebilir. Güçlü (2017)'ye göre, okulların daha etkili bir performans gösterebilmeleri noktasında öğretmenlerin ve diğer kurum çalışanlarının okulu tanımaları, okulun amaçlarını bilmeleri, işlerin nasıl yürüdügünü anlamaları ve okulun kültürünü benimsemeleri fark yaratarak verimliliği arttırabilir. Dolayısıyla okula yönelik bu uyum sürecinin zamanla gelişebileceği, dolayısıyla da informal iletişim kanallarının da kullanımının artabileceği ifade edilebilir. Bir okulda farklı bölümlerin mevcut olması, öğrencilerin düşük performansları, öğretmenlerin olumsuz tutumları vb. nedenlerle okul kültürü bağlamında farklılaşan mesleki ve teknik liselerde informal iletişim kanallarının gelişmesinin daha da güçleşeceği ve zaman alacağı söylenebilir. Bir okulda çalışma süresinin artmasılyla informal iletişim kanallarının daha da aktifleşeceği, bu durumun mesleki ve teknik liseler bağlamında daha da belirginleşeceği ileri sürülebilir.

Son olarak, mesleki ve teknik liselerde görev yapmakta olan okul yöneticileri ve öğretmenlerin informal iletişim algılarının okulda mezun olunan fakülteye göre farklılık gösterdiği, bu farklılığın Eğitim Fakültesi mezunları ile Fen Edebiyat Fakültesi mezunları arasında olduğu bulgusu elde edilmiştir. Eğitim Fakültesi mezunlarının Fen Edebiyat Fakültesi mezunlarına göre informal iletişim düzeyleri daha yüksektir. Bu bulgunun öğretmenlerin aldıkları pedagojik eğitimle ilgili olabileceği düşünülmektedir. Eğitim fakültesinden mezun olan öğretmenlerin lisans öğrenimleri boyunca aldıkları iletişim ile ilgili derslerin mesleki yaşamlarına olumlu katkılarının olabileceği, Fen Edebiyat fakültesi mezunlarında ise daha sıkıştırılmış bir şekilde alınan bu derslerin nispeten daha az katk1 sağlayabileceği söylenebilir. 


\section{SONUÇ ve ÖNERILLER}

$\mathrm{Bu}$ araştırmada mesleki ve teknik liselerdeki informal iletişimin orta düzeyde olduğu tespit edilmiştir. Diğer okullarda gerçekleştirilen araştırmalarda ise informal iletişim düzeyinin daha yüksek olduğu göz önüne alındığında mesleki ve teknik liselerdeki informal iletişim düzeyi dikkat çekicidir. Okulların informal yanının daha ağır olan örgütler olması, etkinliklerinin temelinde paydaşlarıyla güçlü iletişim olması, etki alanının geniş olması gibi kendine has özellikleri göz önüne alındığında bu bulgunun derinlemesine araştırılmaya ihtiyacı olduğunu söylemek mümkündür. Kalifiye insan gücü yetiştirmede önemli rolü olan mesleki ve teknik liselerde informal iletişim kanallarının daha aktif kullanılmasıyla yardımlaşma, motivasyon, performans ve üretim güçlerinin artacağ 1 söylenebilir. Araştırma bulgularından hareketle informal iletişimle ilgili olarak mesleki ve teknik liselerde görev yapmakta olan yönetici ve öğretmenlere bazı eğitimler, atölye çalışmaları düzenlenebilir. Aynı bölümler içerisinde ve bölümler arasında iletişimi arttırabilecek sosyal ve kültürel organizasyonlar yapılabilir.

\section{KAYNAKÇA}

Afat, N., ve Arslan, N. (2019). Öğretmenlerin informal iletişim düzeyleri ile örgütsel sinizm arasındaki ilişkinin incelenmesi. IZZ̈̈ Eğitim Dergisi, 1(2), 218-249

Arabac1, İ. B., Sünkür, M., ve Şimşek, F. Z. (2012). Öğretmenlerin dedikodu ve söylenti mekanizmasına ilişkin görüşleri: Nitel bir çalışma. Kuram ve Uygulamada Eğitim Yönetimi, 2(2), 171-190.

Atalay Mazlum, A., ve Balcı, A. (2018). Meslek lisesi öğretmen ve öğrencilerine göre okul: Bir metafor çalışması. Mehmet Akif Ersoy Üniversitesi Eğitim Fakültesi Dergisi, (47), 1-26.

Ay, D., ve Uğurlu, C. T. (2016). Öğretmenlerin kişilerarası öz-yeterlikleri ve informal iletişimleri: Nicel bir çalışma. İnönü Üniversitesi Ĕgitim Bilimleri Enstitüsü Dergisi, 3(5), 28-47.

Aydın, M. (2013). Eğitimde örgütsel davranış. Gazi kitabevi.

Bektaş, M., ve Erdem, R. (2015). Örgütlerde informal iletişim süreci: Kavramsal bir çerçeve. Afyon Kocatepe Üniversitesi İktisadi ve İdari Bilimler Fakültesi Dergisi, 17(1), 125-139.

Bolat, S.(1996). Eğitim örgütlerinde iletişim: H.Ü.Eğitim Fakültesi uygulaması. Hacettepe Üniversitesi Eğitim Fakültesi Dergisi, 12, 75-80 
Bursalığlu, Z. (2012). Okul yönetiminde teori ve uygulama. Ankara Üniversitesi Eğitim Fakültesi Yayınları.

Bursalığlu, Z. (2012). Okul yönetiminde yeni yapı ve davranış. Pegem.

Büyüköztürk, Ş., Kılıç-Çakmak, E., Akgün, Ö., Karadeniz, Ş., ve Demirel, F. (2017). Bilimsel araştırma yöntemleri. Pegem Akademi.

Can, A. (2017). SPSS ile bilimsel araştırma sürecinde nicel veri analizi. Pegem Akademi.

Crampton, S. M., Hodge, J. W., and Mishra, J. M. (1998). The informal communication network: Factors influencing grapevine activity. Public Personnel Management, 27(4), 569-584.

Eğinli, A., ve Bitirim, S. (2008). Kurumsal başarının önündeki engel: Zehirli (toksik) iletişim. Selçuk İletişim, 5(3), 124-140.

Ergen, E. (2011). Turning the informal communication network of an organization into a knowledge tool through communities of practice. Management, Konowlwedge and Learning Conference. Thessaloniki, Greece.

Fay, M. J., and Kline, S. L. (2012) The influence of informal communication on organizational identification and commitment in the context of highintensity telecommuting, Southern Communication Journal, 77(1), 61-76.

Güçlü, M. (2017). Örgütsel iletişim: Eğitim kurumlarındaki yeri ve önemi açısından bir değerlendirme. OPUS Uluslararası Toplum Araştırmaları Dergisi, 7(13), 854-870.

Gürsel, M. (2006). Eğitimde yönetim ve sisteme ilişkin çeşitlemeler. Eğitim Kitabevi.

Himmetoğlu, B., Ayduğ, D., ve Bayrak, C. (2020). Okul yöneticilerinin okullarda resmi olmayan bir iletişim türü olarak söylenti ve dedikodu ağına ilişkin görüşleri. Çukurova Üniversitesi Eğitim Fakültesi Dergisi, 49 (1), 45-72.

Hoy, W. K., ve Miskel, C. G. (2010). Eğitim Yönetimi, Teori, Araştırma ve Uygulama (S. Turan, Çev.). Nobel Yayıncılık.

Karaçor, S., ve Şahin, A. (2004). Örgütsel iletişim kurma yöntemleri ve karş1laş1lan iletişim engellerine yönelik bir araştırma. Sosyal Ekonomik Araştırmalar Dergisi, 4(8),96-117. 
Karcıoğlu, F., Timuroğlu, K., ve Çınar, O. (2009). Örgütsel iletişim ve iş tatmini ilişkisi-bir uygulama. İstanbul Üniversitesi İsletme İktisadi Enstitüsü Dergisi-Yönetim, (67), 59-76

Kraut, R. E., Fish, R. S., Root, R. W. and Chalfonte, B. L. (1990). Informal communication in organizations: Form, function, and technology (I. S. Oskamp and S. Spacapan, Eds). Human reactions to technology: Claremont symposium on applied social psychology in (145-199), SAGE Publications.

Lohman, M. C. (2006). Factors influencing teachers' engagement in informal learning activities. Journal of Workplace Learning, 18(3), 141-156.

Lunenburg, F. C. (2010). Communication: The process, barriers, and improving effectiveness. Schooling, 1(1), 1-10.

Memduhoğlu, H. B., ve Saylık, A. (2012). Okullarda informel ilişkiler ölçeğinin geliştirilmesi ve bazı değişkenler açısından incelenmesi. Yüzüncü Yıl Üniversitesi Ĕ̈itim Fakültesi Dergisi, 9(1), 1-22.

Mert, İ. S., Bekmezci, M., ve Eroğluer, K. (2019). Gayri resmi iletişimin örgütsel bağl11ı üzerindeki etkisi. Gümüşhane Üniversitesi Illetişim Fakültesi Elektronik Dergisi, 7(1), 1-27.

Riggio, R. E. (2016). Endüstri ve örgüt psikolojisine giriş (B. Özkara, Çev.). Nobel Akademik Yayıncılık.

Robbins, S. P. ve Judge, T. (2013). Örgütsel davranış. Nobel.

Sönmez, M. A. (2006). Meslek liselerinde örgüt kültürü. Kuram ve Uygulamada Ĕ̈itim Yönetimi, 45(45), 85-108.

Subramanian, S. (2006). An "open eye and ear" approach to managerial communication. Vision, 10(2), 1-10.

Toytok, E. H., ve Doğan, E. (2019). Okullarda informel iletişimi kullanma ölçeği geliştirme çalışması. Elektronik Sosyal Bilimler Dergisi, 18(70), 852-865.

Uğurlu, C. (2014). İnformal iletişim ölçeği: Geçerlik ve güvenirlik çalışması. İnönü Üniversitesi Eğitim Fakültesi Dergisi, 15(3), 83-100.

Ustun, M., and Bostanci, A. B. (2021). The relationships between the informal communication levels in schools and the psychological capital of the teachers. European Journal of Education Studies, 8(2), 152-180. 